\title{
Crop Management Practices and Labor Inputs for Hop Production in Florida ${ }^{1}$
}

\author{
Shinsuke Agehara, Mariel Gallardo, Aleyda Acosta-Rangel, Zhanao Deng, Jack Rechcigl, \\ Tianyuan Luo, and Qi Qiu²
}

Hops (Humulus lupulus L.) are an emerging specialty crop in Florida. Hop cones, or strobiles, are used as an essential ingredient in brewing to add bitterness and aroma to beer. The booming craft beer industry, rising prices of hops, and demand for locally produced ingredients have recently increased interest in local hop production among growers and brewers. Like other specialty crops, hops require intensive crop management. This article describes crop management practices and labor inputs required for small-scale hop production in Florida to assist growers with making investment and farm management decisions. It is part of a series of Extension articles that will review the challenges of hop production in Florida, based on research experience at the UF/IFAS Gulf Coast Research and Education Center (UF/IFAS GCREC) in Balm, FL.

\section{Introduction}

The US hop industry has experienced significant growth since 2000. From 2000 to 2020, the US hop production volume, acreage, and farm gate price increased by $54 \%$, $62 \%$, and $219 \%$, respectively (US Department of Agriculture-NASS 2020). In 2020, hops were harvested on 58,641 acres, the highest acreage on record since 1915 (US Department of Agriculture-NASS 2020). The Pacific Northwest states, including Washington, Oregon, and Idaho, supply over $90 \%$ of hops in the United States (US Department of Agriculture-NASS 2020).

The rapid growth of the hop industry has been driven primarily by the nation's fast-growing craft brewing industry. In 2019 , craft beer retail sales were $\$ 29.3$ billion, accounting for more than $25 \%$ of the $\$ 116$ billion US beer market (Brewers Association 2019a). The craft beer movement also boomed in Florida. From 2011 to 2019, the number of Florida craft breweries increased from 45 to 329. In 2019, Florida produced 42.6 million gallons of craft beer, ranking fourth in the nation and generating an economic impact of $\$ 3.8$ billion (Brewers Association 2019b). In our surveys, many Florida craft breweries expressed strong interest in using locally grown hops.

At the UF/IFAS GCREC, researchers are currently conducting various research trials to develop recommendations to grow this emerging crop in Florida. Florida's hop production system is unique because of the subtropical climate. First, hops are grown with LED supplemental lighting to promote flowering at the optimum growth stage (Agehara 2020, https://edis.ifas.ufl.edu/hs1365). Second, Florida can produce two crops a year because of its short and mild winters, whereas other production regions can harvest hops only once a year. Consequently, hops grown under

1. This document is HS1409, one of a series of the Horticultural Sciences Department, UF/IFAS Extension. Original publication date March 2021. Visit the EDIS website at https://edis.ifas.ufl.edu for the currently supported version of this publication.

2. Shinsuke Agehara, assistant professor; Mariel Gallardo, graduate research assistant; Aleyda Acosta-Rangel, former postdoctoral associate; Horticultural Sciences Department; Zhanao Deng, professor, Environmental Horticulture Department; Jack Rechcigl, center director and professor, Department of Soil and Water Sciences; Tianyuan Luo, postdoctoral associate; and Qi Qiu, former graduate research assistant; Food and Resource Economics Department; UF/IFAS Gulf Coast Research and Education Center, Balm, FL 33598.

The Institute of Food and Agricultural Sciences (IFAS) is an Equal Opportunity Institution authorized to provide research, educational information and other services

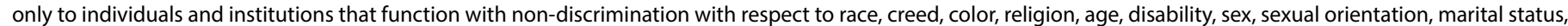

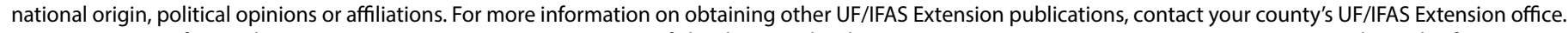
U.S. Department of Agriculture, UF/IFAS Extension Service, University of Florida, IFAS, Florida A \& M University Cooperative Extension Program, and Boards of County Commissioners Cooperating. Nick T. Place, dean for UF/IFAS Extension. 
this production system require different crop management practices and labor inputs compared to traditional production systems.

\section{Growth Characteristics}

Hops are herbaceous perennial plants in the Cannabaceae family. Hops are dioecious, meaning individual plants are either male or female. Female hop plants produce female flowers, which develop into cones, or strobiles. Mature hop cones produce lupulin, a yellowish resinous substance. Acids and essential oils contained in lupulin glands are important for brewing because they impart bitterness, flavor, and stability to beer.

Hop plants develop twining stems called bines, which climb with the help of stiff hairs along their stems. Hop bines grow rapidly, with a peak growth of up to 10 inches a day (Sirrine 2014). Because of this climbing growth habit, commercially grown hop plants are trained to grow up on a high trellis, typically 12 to $18 \mathrm{ft}$ tall (Dodds 2017). Coir twines are commonly used for growing hops on a trellis.

The commercial hop harvesting process generally involves two steps. The first step is to cut down bines: individual bines are cut at the bottom and then at the top. The second step is to separate hop cones from stems and leaves using a harvester. Videos of the hop harvesting process at the UF/ IFAS GCREC are available on YouTube at the following link: https://youtube.com/playlist?list=PL4qrij3jZ6i5Bwgyl gUcb6fMI0z9FKCkQ.

\section{Source of Information}

This article describes crop management practices and labor required to produce hops on a 1-acre hop yard with an 18 $\mathrm{ft}$ tall straight trellis (Agehara, Acosta-Rangel, Deng, et al. 2020, https://edis.ifas.ufl.edu/hs1354). The information was collected at the UF/IFAS GCREC in 2018 and 2019. Most crop management practices in this article reflect commercial practices commonly used for small-scale hop production.

\section{In-Season Crop Management and Timeline}

Table 1 describes crop management activities for hop production, and Table 2 shows the frequency of each activity. Because hop bines grow vertically on a high trellis, they require labor-intensive management, including twine installation, trellising, trimming, and pruning. In addition, growing hops in subtropical climates requires some unique crop management practices, such as supplemental lighting and pine bark application. Supplemental lighting is critical for successful hop production in subtropical climates, where natural day length induces premature flowering and does not promote adequate bine growth (Agehara, AcostaRangel, Deng, et al. 2020, https://edis.ifas.ufl.edu/hs1354). Application of pine bark fines to cover the open ground around plants is recommended for weed control.

In Florida, hops have two growth cycles per year. The spring season is from February to June, and the fall season is from June to November. Plants go dormant in late December. The emergence of new bines occurs between mid-February and early March, depending on the cultivar. Consequently, field activities are minimal in January. Same crop management activities are performed in both spring and fall seasons. The frequency of mowing and crop scouting is higher in the fall season than in the spring, whereas the frequency of other crop management activities is similar in both seasons. The video describing spring and fall growth cycles of hops in Florida is available on YouTube at the following link: https://youtu.be/_rAnXr3cQrs.

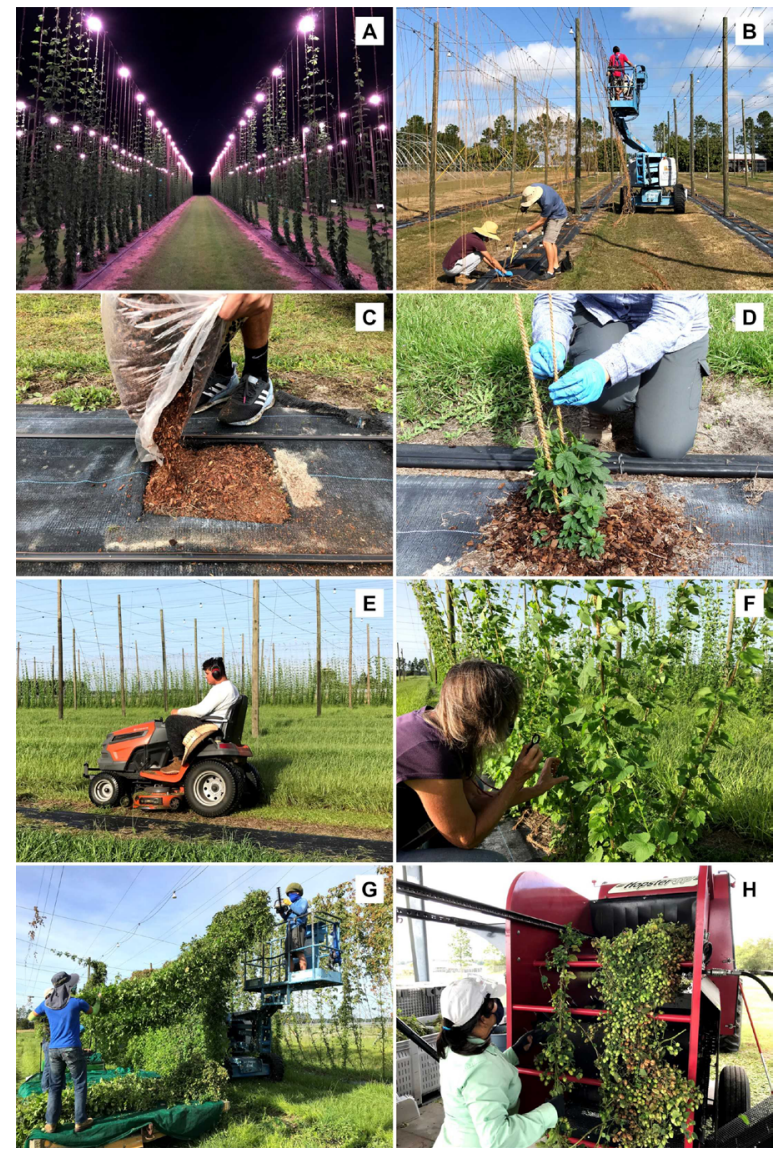

Figure 1. Crop management practices required for hop production in Florida: (A) LED supplemental lighting. (B) twine installation, (C) pine bark application, (D) bine training and pruning, (E) mowing, (F) crop scouting, (G) harvesting bines, and $(\mathrm{H})$ separating cones from stems and leaves using a harvester.

Credits: Shinsuke Agehara, UF/IFAS 


\section{Labor Inputs}

Table 3 shows the labor required to produce hops on a 1 -acre farm. Hops are a perennial crop that generally takes a few years to reach its maximum yield potential. Therefore, during the first few years, the labor to manage hops increases as plants grow more vigorously. In Year 1, the seasonal labor inputs were 292 and 320 hours per acre in the spring and fall seasons, respectively. In Year 2, the seasonal labor inputs were 323 and 334 hours per acre in the spring and fall seasons, respectively. The seasonal labor inputs increased from the spring to fall season by $10 \%$ in Year 1 (292 vs. 320 hours per acre) and by 3\% in Year 2 (323 vs. 334 hours per acre). The annual labor inputs increased by $7 \%$ from Year 1 to Year 2 (616 vs. 657 hours per acre).

Harvesting was the most labor-intensive activity, accounting for $42 \%$ to $51 \%$ (134 to 162 hours per acre) of the seasonal labor inputs. The second, third, and fourth most labor-intensive activities were mowing, bine training and pruning, and twine installation, which accounted for $10 \%$ to $17 \%$ (33 to 54 hours per acre), $10 \%$ to $13 \%$ (30 to 40 hours per acre), and $10 \%$ to $12 \%$ (34 hours per acre) of the seasonal labor inputs, respectively. The sum of these labor inputs represented $82 \%$ to $84 \%$ of the seasonal labor inputs. Other crop management activities required only 4 to 11 hours per acre, accounting for $1 \%$ to $3 \%$ of the seasonal labor inputs.

Some crop management activities showed seasonal changes in the required labor inputs. For example, because plants did not require pruning during the establishment season, bine training and pruning were less labor intensive in the first growing season than in the following growing seasons. Mowing, crop scouting, and hand weeding were more labor intensive in the fall growing season than in the spring growing season. By contrast, harvesting was more labor intensive in the spring season because of more dense bine growth and higher yield. Labor inputs for harvesting increased by $10 \%$ from Year 1 to Year 2 (282 vs. 310 hours per acre).

Hop harvesting generally involves two steps: (1) cutting down bines in the field, and (2) separating cones from stems and leaves using a harvester. The labor required for each step varies considerably depending on the method and farm equipment. At the UF/IFAS GCREC, the first step is performed manually using a hedge trimmer (Figure $1 \mathrm{G})$, and the second step is performed mechanically using a mobile hop harvester (Hopster 5P; HopsHarvester LLC, Honeoye Falls, NY) (Figure 1H) suitable for a small operation of 1 to 3 acres. When the production scale is expanded, harvesting labor can be reduced significantly by implementing large-scale harvesting equipment.

\section{Concluding Remarks}

In this study, the need for insecticide and fungicide application was determined based on weekly crop scouting. Surprisingly, labor inputs for pest management (insecticide and fungicide spray) were minimal, although Florida's environmental conditions are generally conducive to disease development. We did not use any fungicide, but no major disease was observed in four consecutive growing seasons. Insecticides were sprayed only to control spider mites.

To date, Florida does not have production issues with pathogens typically associated with hop production throughout the world, including downy mildew (Pseudoperonospora humuli), powdery mildew (Podosphaera macularis), and several destructive hop viruses and viroids (Agehara, Acosta-Rangel, Gallardo, et al. 2020, https://edis. ifas.ufledu/hs1381). To avoid the possibility of introducing these pathogens into the state, we do not recommend using rhizomes and cuttings as planting material because of the high likelihood of infection with the pathogens. Florida growers are strongly encouraged to use tissue-culture seedlings that are certified virus-free.

In the hopyard established at the UF/IFAS GCREC, we found that stunted and chlorotic hop plants were severely infested with nematodes (Desaeger 2018, https://edis.ifas. ufl.edu/in1229). It is important to implement preventative management strategies during hopyard establishment to minimize the impact of nematodes on hop production. Use of nematode-free planting material and preventative measures can also minimize the cost and labor required for nematode management. For nematode management guidelines, see https://edis.ifas.ufl.edu/in1229 (Desaeger 2018) and https://edis.ifas.ufl.edu/hs1354 (Agehara, AcostaRangel, Deng, et al. 2020).

Because our employees are not as trained as commercial farm workers to manage this emerging crop, the labor information in this article could be somewhat overestimated. Furthermore, some crop management practices are not yet optimized, and there is room for improvement. The information in this article will be revised as we gain more experience and improve crop management in the future. 


\section{Literature Cited}

Agehara, S. 2020. "Using Supplemental Lighting to Control Flowering of Hops in Florida." EDIS 2020 (2). https://doi.

org/10.32473/edis-hs1365-2020

Agehara, S., A. Acosta-Rangel, Z. Deng, J. Rechcigl, and S. Bollin. 2020. "Hop Yard Establishment and Trellis Construction in Florida." EDIS 2020 (1): 7. https://doi. org/10.32473/edis-hs1354-2020

Agehara, S., A. Acosta-Rangel, Mariel Gallardo, and Gary Vallad. 2020. "Selection and Preparation of Planting Material for Successful Hop Production in Florida." EDIS 2020 (5). https://doi.org/10.32473/edis-hs1381-2020

Brewers Association. 2019a. "National Beer Sales \& Production Data." Accessed January 6, 2021. https://www.brewersassociation.org/statistics-and-data/national-beer-stats/

Brewers Association. 2019b. "Florida's Craft Beer Sales and Production Statistics, 2019.” Accessed January 6, 2021. https://www.brewersassociation.org/statistics-and-data/ state-craft-beer-stats $/$ ?state $=$ FL

Desaeger, J. 2018. "Nematodes Parasitizing Hops in Florida.” ENY071. EDIS 2018 (6). https://doi.org/10.32473/ edis-in1229-2018

Dodds, K. 2017. "Hops: A Guide for New Growers." NSW Department of Primary Industries. Accessed August 26, 2020. https://www.dpi.nsw.gov.au/_data/assets/ pdf_file/0007/712717/hops-guide-for-new-growers.pdf

Sirrine, R. 2014. Growing Hops. E3210. East Lansing: Michigan State University. https://www.canr.msu.edu/ uploads/resources/pdfs/growing_hops_(e3210).pdf

US Department of Agriculture-National Agricultural Statistics Service. 2020. "Quick Stats.” Accessed January 6, 2021. https://quickstats.nass.usda.gov/ 
Table 1. Crop management activities performed to grow hops at the UF/IFAS GCREC.

\begin{tabular}{|l|l|}
\hline \multicolumn{1}{|c|}{ Crop Management } & \multicolumn{1}{c|}{ Activity } \\
\hline Irrigation system maintenance & Maintain drip irrigation and injection systems; repair irrigation leaks; refill fertilizer tanks \\
\hline Lighting system maintenance & Maintain LED supplemental lighting system installed on a trellis \\
\hline Trimming & Cut back remaining bines near the ground level at the beginning of the growing season \\
\hline Twine installation & Install twines on a trellis \\
\hline Pine bark application & Apply pine bark fines around the plants for weed control \\
\hline Bine training and pruning & Train four bines per twine and prune extra bines \\
\hline Mowing & Mow grass grown between rows by a mower \\
\hline Crop scouting & Assess pest pressure and crop performance weekly \\
\hline Hand weeding & Pull weeds by hand around the plants \\
\hline Herbicide spray & Herbicide spray on planting bed edges \\
\hline Insecticide and fungicide spray & Pesticide spray on hop bines by a sprayer \\
\hline Harvesting & Cut off bines in the field; separate cones from stems and leaves with a harvester \\
\hline
\end{tabular}

Table 2. The frequency of crop management activities performed for the second-year hop plants at the UF/IFAS GCREC in 2019.

\begin{tabular}{|c|c|c|c|c|c|c|c|c|c|c|c|c|c|c|c|}
\hline \multirow[t]{3}{*}{ Crop Management } & \multicolumn{15}{|c|}{ Activity Frequency ${ }^{1}$} \\
\hline & \multicolumn{6}{|c|}{ Spring Season } & \multicolumn{6}{|c|}{ Fall Season } & \multirow[t]{2}{*}{ Spring } & \multirow[t]{2}{*}{ Fall } & \multirow[t]{2}{*}{ Total } \\
\hline & Jan & Feb & Mar & Apr & May & Jun & Jul & Aug & Sep & Oct & Nov & Dec & & & \\
\hline $\begin{array}{l}\text { Irrigation system } \\
\text { maintenance }\end{array}$ & 1 & 1 & 1 & 1 & 1 & 1 & 1 & 1 & 1 & 1 & 1 & 1 & 6 & 6 & 12 \\
\hline $\begin{array}{l}\text { Lighting system } \\
\text { maintenance }\end{array}$ & & 1 & & & & & 1 & & & & & & 1 & 1 & 2 \\
\hline Trimming & & 1 & & & & & 1 & & & & & & 1 & 1 & 2 \\
\hline Twine installation & & 1 & & & & & 1 & & & & & & 1 & 1 & 2 \\
\hline Pine bark application & & 1 & & & & & 1 & & & & & & 1 & 1 & 2 \\
\hline Bine training and pruning & & & 4 & 4 & & & 2 & 5 & & & & & 8 & 7 & 15 \\
\hline Mowing & & 1 & 2 & 2 & 3 & 3 & 4 & 5 & 3 & 3 & 3 & & 11 & 18 & 29 \\
\hline Crop scouting & & & 4 & 4 & 4 & 4 & 4 & 4 & 4 & 4 & 4 & & 16 & 20 & 36 \\
\hline Hand weeding & & & 1 & 1 & 1 & & 1 & 1 & 1 & 1 & & & 3 & 4 & 7 \\
\hline Herbicide spray & & & 1 & & 1 & & 1 & & 1 & & & & 2 & 2 & 4 \\
\hline $\begin{array}{l}\text { Insecticide and fungicide } \\
\text { spray }\end{array}$ & & & 1 & 1 & 1 & 1 & & 1 & 1 & 1 & 1 & & 4 & 4 & 8 \\
\hline Harvesting & & & & & & 1 & & & & & & 1 & 1 & 1 & 2 \\
\hline
\end{tabular}


Table 3. Labor inputs required for crop management activities to manage first- and second-year hops in Florida. ${ }^{1}$

\begin{tabular}{|c|c|c|c|c|c|c|}
\hline \multirow[b]{2}{*}{ Crop Management } & \multicolumn{6}{|c|}{ Labor (hours/acre) } \\
\hline & Year 1 Spring & Year 1 Fall & Year 2 Spring & Year 2 Fall & Year 1 Total & Year 2 Tota \\
\hline Irrigation system maintenance & 8 & 8 & 8 & 8 & 16 & 16 \\
\hline Lighting system maintenance & 5 & 5 & 5 & 5 & 10 & 10 \\
\hline Trimming & 0 & 7 & 7 & 7 & 7 & 14 \\
\hline Twine installation & 34 & 34 & 34 & 34 & 68 & 68 \\
\hline Pine bark application & 9 & 9 & 9 & 9 & 18 & 18 \\
\hline Bine training and pruning & 30 & 40 & 40 & 40 & 70 & 80 \\
\hline Mowing & 33 & 54 & 33 & 54 & 87 & 87 \\
\hline Crop scouting & 8 & 10 & 8 & 10 & 18 & 18 \\
\hline Hand weeding & 9 & 11 & 9 & 11 & 20 & 20 \\
\hline Herbicide spray & 4 & 4 & 4 & 4 & 8 & 8 \\
\hline Insecticide and fungicide spray & 4 & 4 & 4 & 4 & 8 & 8 \\
\hline Harvesting & 148 & 134 & 162 & 148 & 282 & 310 \\
\hline TOTAL & 292 & 320 & 323 & 334 & 612 & 657 \\
\hline
\end{tabular}

